\title{
Comparison of traits of non-colonized and colonized decaying logs by vascular plant species
}

\author{
Damian Chmura ${ }^{(1)}$, \\ Jan Zarnowiec ${ }^{(1)}$, \\ Monika Staniaszek-Kik ${ }^{(2)}$
}

\begin{abstract}
The main goal of this study was to check whether the process of the colonization of coarse woody debris (CWD) is random or is determined by the wood traits and the environment. The study was conducted in the Karkonosze Mts., a part of Sudeten Mts. (Poland). We recorded the CWD traits and site conditions for 453 logs of spruce (Picea abies) and beech (Fagus sylvatica), which were either colonized or not colonized by vascular plants. Principal Components Analysis (PCA), a statistical comparison of two categories of logs using the Wilcoxon's sum rank test and Generalized Linear Model (GLM) were applied. $P$. abies logs were colonized significantly more frequently than $F$. sylvatica logs. PCA demonstrated that the groups of colonized and non-colonized logs significantly differed overall in both species. The colonization status of a given log was significantly associated with CWD traits and site conditions. Decomposition class, the log diameter and the cover of bryophytes in $F$. sylvatica and $P$. abies, as well as altitude in the latter species, were significant factors that increased the probability of dead wood colonization by vascular plants. The results supported the hypothesis that vascular plants do not colonize all of the available logs and that the process of establishment is not random.
\end{abstract}

Keywords: Dead Wood, Fallen Trees, Succession, Norway Spruce, Beechwood, Montane Forest

\begin{abstract}
Introduction
Colonization of coarse woody debris (CWD) by vascular plants has received less attention from researchers than colonization by other groups of organisms, e.g., bryophytes, lichens, fungi and insects (Jüriado et al. 2003, Odor \& Van Hees 2004, Ols et al. 2013, Sefidi \& Etemad 2015). Nevertheless, there is some literature evidence stressing that CWD, especially decaying logs, can serve as habitats for some herbaceous and woody plants in both lowland and montane forests (Zielonka \& Piatek 2004, Dittrich et al. 2014, Nowinska et al. 2009, Checko et al. 2015). It is commonly acknowledged that the decomposition stage of decaying logs is one of the most important factors for the recruitment, survival and completion of the life cycle of wood-dwelling vascular plants. During de-

cay, a temporal turnover among species can be observed, thus the process of colonization resembles succession (Zielonka \& Piatek 2004). Decaying fallen trees can especially serve as "nurse logs" for tree seedlings. This phenomenon is particularly wellknown in spruce (Brang et al. 2003, Kupferschmid \& Bugmann 2005, Zielonka 2006). All of the aforementioned studies were devoted to coarse woody debris that was already colonized, but not all logs are colonized by plants. Some logs, even if they are strongly decomposed, are free of vascular plants, although they may be colonized by cryptogams. In Central Europe, no obligatory epixylic vascular plant species are known. Here we aimed to understand whether the process of colonization is random or is determined by the traits of CWD and the environment. It can be assumed
\end{abstract}

(1) Institute of Environmental Protection and Engineering, University of Bielsko-Biala, ul. Willowa 2, 43-309 Bielsko-Biala (Poland); (2) Department of Geobotany and Plant Ecology, University of Lodz, ul. Banacha 12/16, 90-237 Lódz (Poland)

@ Damian Chmura (dchmura@ath.bielsko.pl)

Received: May 08, 2016 - Accepted: Oct 25, 2017

Citation: Chmura D, Zarnowiec J, Staniaszek-Kik M (2018). Comparison of traits of noncolonized and colonized decaying logs by vascular plant species. iForest 11: 11-16. - doi: 10.3832/ifor2107-010 [online 2018-01-09]

Communicated by: Gianluca Piovesan that decomposition is an important factor at the beginning of colonization by vascular plant species, but perhaps it is not the only important variable. We wanted to find out whether the properties of a decaying log in terms of its length, surface area or species identity as well as the location of a log can influence the probability of colonization and its frequency. Therefore, we compared colonized and non-colonized logs and tested whether the likelihood of colonization depends on log characteristics or location. We hypothesized that the colonization of dead wood by vascular plants is not accidental and that colonized logs differ from non-colonized logs. Moreover, we hypothesized that some intrinsic and extrinsic variables may increase the probability of the colonization of logs.

\section{Material and methods}

\section{Study site}

The study was conducted in two forest montane belts in the area of the Karkonosze Mts. - a lower forest montane belt (500-1000 $\mathrm{m}$ a.s.l.) and an upper forest montane belt (1000-1250 $\mathrm{m}$ a.s.l.). The forested areas occupy about $70 \%$ of the Karkonosze Mts., which amounts to 13,505 ha. The most common tree is the spruce (Picea abies, $\approx 90 \%$ ), followed by the beech (Fagus sylvatica, 3\%), Scots pine (Pinus sylvestris, 3\%), the birch (Betula pendula, $2 \%)$, and others (2\%). Spruce occurs naturally in the upper montane forest belt 
where it forms a monospecific forest community Calamagrostio villosae-Piceetum (CVP), whereas in the lower montane zone, Picea abies forest has been planted (PA PF), which is the result of past cultivation. Beech (F. sylvatica) occurs naturally in the lower forest montane belt where it forms several phytocoenoses, e.g., acidophilus beech woods and fertile montane beech forests (Fagetalia, F). Both tree species can be found in a fir-spruce mixed coniferous forest (Abieti-Piceetum, AP).

\section{Data collection}

A total 185 plots $(10 \times 10 \mathrm{~m})$ were established using a random-stratified sampling (Chmura et al. 2016). The collection of data was stratified by forest type. A map of the potential vegetation and forest inventories was used to cover the four distinguished forest communities within the lower montane belt and the upper montane belt (Tab. 1). The study plots were searched for the presence of decaying logs. Only logs longer than $0.5 \mathrm{~m}$ having a lower (at the wider end) diameter greater than $0.1 \mathrm{~m}$ were included in the study. A total of 453 logs were positioned using a GPS device, including 273 logs that had been colonized by vascular plant species. The logs belonged to two tree species - Picea abies and Fagus sylvatica. The environmental data that were gathered comprised two types of data - the characteristics of the logs and the characteristics of the sites on which the logs were located. These were the area of the log surface available to plants, hereafter referred to as AREA $\left(\mathrm{m}^{2}\right)$. It was calculated as follows (eqn. 1, eqn. 2 ):

$$
\begin{aligned}
& \text { Area }=\frac{2}{3} \cdot S A \\
& S A=\pi L(R+r)+\pi R^{2}+\pi r^{2}
\end{aligned}
$$

where $S A$ is the log surface, $L$ is the length of $\log , R$ is the radius of lower and $r$ the radius of upper diameter. The length of a log was labelled as LENGTH $(\mathrm{m})$ and the mean of the lower (LOWER) and upper (UPPER) diameter as a DIAMETER $(\mathrm{cm})$. The decomposition stage (DECOMPOSITION) was assessed on an eight-degree scale after Holeksa (2001) and Zielonka \& Piatek (2004) while the moisture of a log (1-3 degree scale) was labelled as MOISTURE (1: dry, completely dry to the touch; 2 : intermediate, slightly perceptible moisture to the touch; 3: moist, water flows when pressure is applied) and the cover of bryophytes as BRYOPHYTES (\%). Those data that are related to site characteristics were the shade (SHADE), evaluated on a 1-5 degree scale (1: <30\% of canopy cover; 2 : 30-40\%; 3: 40$60 \%$;: 60-80\%; 5: >80\%), and the altitude

Tab. 1 - Altitude of the location of logs, number of studied logs according to selected factors and their characteristics. (F): Fagetalia, beechwood; (PA_PF): Picea abies plantations; (AP): Abieti-Piceetum, fir-spruce mixed coniferous forest; (CVP): Calamagros-

\begin{tabular}{|c|c|c|c|}
\hline Factors & Class / Statistic & $\begin{array}{c}\text { Beech } \\
(n=113)\end{array}$ & $\begin{array}{c}\text { Spruce } \\
(n=340)\end{array}$ \\
\hline \multirow{4}{*}{$\begin{array}{l}\text { Forest } \\
\text { community }\end{array}$} & F (463-489 m a.s.l.) & 105 & 28 \\
\hline & PA_PF (609-926 $\mathrm{m}$ a.s.l.) & 1 & 97 \\
\hline & AP (709-940 m a.s.l.) & 0 & 127 \\
\hline & CVP (977-1261 m a.s.l.) & 7 & 88 \\
\hline \multirow{2}{*}{$\begin{array}{l}\text { Colonization } \\
\text { Status }\end{array}$} & Colonized & 51 & 222 \\
\hline & Non-Colonized & 62 & 118 \\
\hline \multirow{2}{*}{$\begin{array}{l}\text { Protection } \\
\text { Status }\end{array}$} & Managed Area (9453.5 ha) & 25 & 160 \\
\hline & Protected Area (4051.5 ha) & 88 & 180 \\
\hline \multirow{8}{*}{$\begin{array}{l}\text { Decay Scale } \\
\text { (degrees) }\end{array}$} & 1 & 7 & 16 \\
\hline & 2 & 12 & 44 \\
\hline & 3 & 34 & 59 \\
\hline & 4 & 31 & 89 \\
\hline & 5 & 12 & 35 \\
\hline & 6 & 11 & 61 \\
\hline & 7 & 5 & 30 \\
\hline & 8 & 1 & 6 \\
\hline \multirow{5}{*}{$\begin{array}{l}\text { Area of log } \\
\text { surface }\left(\mathrm{m}^{2}\right)\end{array}$} & Min & 0.5 & 0.3 \\
\hline & $25 \%$ & 2 & 1.2 \\
\hline & Median & 3.8 & 2.1 \\
\hline & $75 \%$ & 7.8 & 3.6 \\
\hline & $\operatorname{Max}$ & 19.9 & 18.6 \\
\hline \multirow[t]{5}{*}{ Length (m) } & Min & 0.7 & 0.5 \\
\hline & $25 \%$ & 2.3 & 2 \\
\hline & Median & 4.5 & 3.5 \\
\hline & $75 \%$ & 7.5 & 6 \\
\hline & Max & 12.1 & 12.4 \\
\hline
\end{tabular}
tio villosae-Piceetum, montane spruce forest.

(ALTITUDE, m a.s.l.), which was measured using GPS.

\section{Data analysis}

The Pearson's chi-square test was used to analyze differences in the frequency of colonization between the $F$. sylvatica and $P$. abies logs. In order to visualize the differences between colonized and non-colonized logs based on all of the studied traits, Principal Components Analysis (PCA) was carried out. The data was standardized prior to this analysis. The colonization status was regarded as a grouping variable and statistically fit onto the ordination. Thus, the analysis of centroids (of two groups of logs) was performed using 999 permutations. The goodness-of-fit statistics, i.e., squared correlation coefficient $r^{2}$ and $p$-value, were calculated in order to check the significance of differences between the colonized and non-colonized logs (Oksanen et al. 2016). Two PCAs were done separately for beech and spruce logs due to the different elevations of $P$. abies and F. sylvatica. The Wilcoxon's sum rank test was applied to compare the traits of colonized and non-colonized logs within the beech logs and spruce logs. Logistic regression was used to assess the probability of the colonization of logs by vascular plants. The response variable was colonization, which was coded as true/false (colonization/non-colonization, respectively). A Generalized Linear Model (GLM) was chosen with the binomial function "logit". Twenty four models were built that included all of the variables, i.e., log traits and site characteristics. The best model was selected based on the Akaike criterion AIC, i.e., the lowest value of AIC was the criterion of the accepted model (Tab. S2 in Supplementary material). The computations of the distribution of a categorical variable (i.e., probability of colonization) and how it changed over a particular numerical variable are shown on conditional density plots. All of the statistics were obtained using suitable routines of the $\mathrm{R}$ software (R Core Team 2015).

\section{Results}

Among the 453 logs studied, 273 (60.2\%) were colonized by at least one species from 46 vascular plant taxa (Tab. S1 in Supplementary material). The contingency table test $\left(d f=1, \chi^{2}=13.56, p<0.0001\right)$ showed that Norway spruce logs were colonized more frequently $(65.3 \%$ colonized log vs. $34.7 \%$ non-colonized logs) than beech logs ( $45.1 \%$ vs. $54.9 \%$ - Fig. 1 ). According to the PCA, the groups of colonized and non-colonized $F$. sylvatica logs were separated along the second axis rather than the first axis (Fig. 2a). There were significant differences between the centroids of the groups of colonized and non-colonized logs $\left(r^{2}=0.10\right.$, $\mathrm{p}<0.001$ ). The first two axes (principal component 1 and 2 ) explained $56.2 \%$ of the $\mathrm{cu}$ mulative variation, whereas the first four explained 79.8\%. Principal Component 1 
was highly loaded for log size AREA, DIAMETER, UPPER and LOWER, whereas principal component 2 was highly loaded for DECOMPOSITION and BRYOPHYTES. In the case of the spruce logs, PCA showed that the centroids of the groups of colonized and non-colonized were separated along both the first and second axis (Fig. 2b). They also differed significantly $\left(r^{2}=0.13\right.$, $p<0.001$ ). The first two axes (principal component 1 and 2 ) accounted for $52.6 \%$ of the cumulative variation, whereas the first four explained $79.1 \%$. The first component of the PCA was highly loaded for UPPER, LOWER and DIAMETER, whereas the second component was highly loaded for BRYOPHYTES, DECOMPOSITION and LENGTH. Taking the differences in the mean parameters of log traits into account, there were significant differences in ALTITUDE, but only for the spruce logs, as colonized logs were generally located at higher altitudes (Tab. 2). The colonized spruce and beech logs had a higher log surface AREA than the non-colonized. In both species colonized logs were characterized by a higher mean DIAMETER and a much higher mean cover of BRYOPHYTES (Tab. 2). The logs were also much more decayed, according to the differences in DECOMPOSITION (Tab. 2). In addition, a higher value of MOISTURE was found in the colonized spruce logs (Tab. 2).

The GLM showed that UPPER and BRYOPHYTES were significant variables in the most optimal model in beech logs (Tab. 3). The most optimal model of logistic regression for spruce showed that ALTITUDE, DECOMPOSITION, LENGTH and BRYOPHYTES were the only significant variables. Predictions about an increase in the

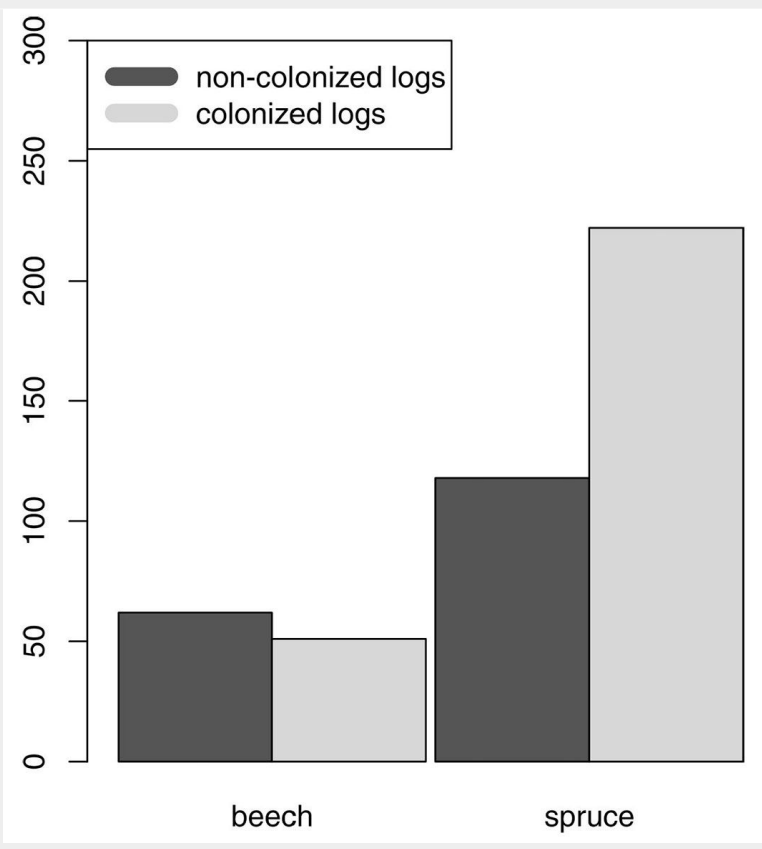

Fig. 1 - Frequency of colonized vs. non-colonized downed trees of beech ( $F$. sylvatica) and spruce ( $P$. abies).

Tab. 2 - Medians \pm IQR of selected variables tested for differences between colonized and non-colonized logs by vascular plants using the Wilcoxon's sum rank test. (*): $\mathrm{p}<0.05 ;(* *): p<0.01 ;(* * *): p<0.001 ;(n s)$ : non-significant.

\begin{tabular}{lcccc}
\hline \multirow{2}{*}{ Variable } & \multicolumn{2}{c}{ Fagus sylvatica } & \multicolumn{2}{c}{ Picea abies } \\
\cline { 2 - 5 } & colonized & non-colonized & colonized & non-colonized \\
\hline ALTITUDE & $551.0 \pm 86.5$ & $565.0 \pm 94.0$ & $907.0 \pm 296.5^{* * *}$ & $828.0 \pm 128.0$ \\
SHADE & $4.0 \pm 0.0$ & $4.0 \pm 0.0$ & $4.0 \pm 1.0$ & $4.0 \pm 0.0$ \\
AREA & $5.0 \pm 7.9^{* *}$ & $3.1 \pm 4.6$ & $2.4 \pm 2.7^{* * *}$ & $1.6 \pm 1.7$ \\
LENGTH & $4.7 \pm 5.7$ & $3.8 \pm 4.5$ & $3.9 \pm 3.9^{*}$ & $2.9 \pm 3.7$ \\
DIAMETER & $0.3 \pm 0.2^{* * *}$ & $0.2 \pm 9.7$ & $0.2 \pm 0.1$ & $0.2 \pm 0.9$ \\
MOISTURE & $2.0 \pm 0.0$ & $2.0 \pm 0.0$ & $2.0 \pm 2.0^{* * *}$ & $2.0 \pm 1.0$ \\
DECOMPOSITION & $4.0 \pm 2.0^{*}$ & $3.0 \pm 1.0$ & $5.0 \pm 2.0^{* * *}$ & $3.0 \pm 2.0$ \\
BRYOPHYTES & $45.0 \pm 34.5^{* * *}$ & $13.0 \pm 35.7$ & $38.0 \pm 44.2$ & $2.0 \pm 6.0$ \\
\hline
\end{tabular}

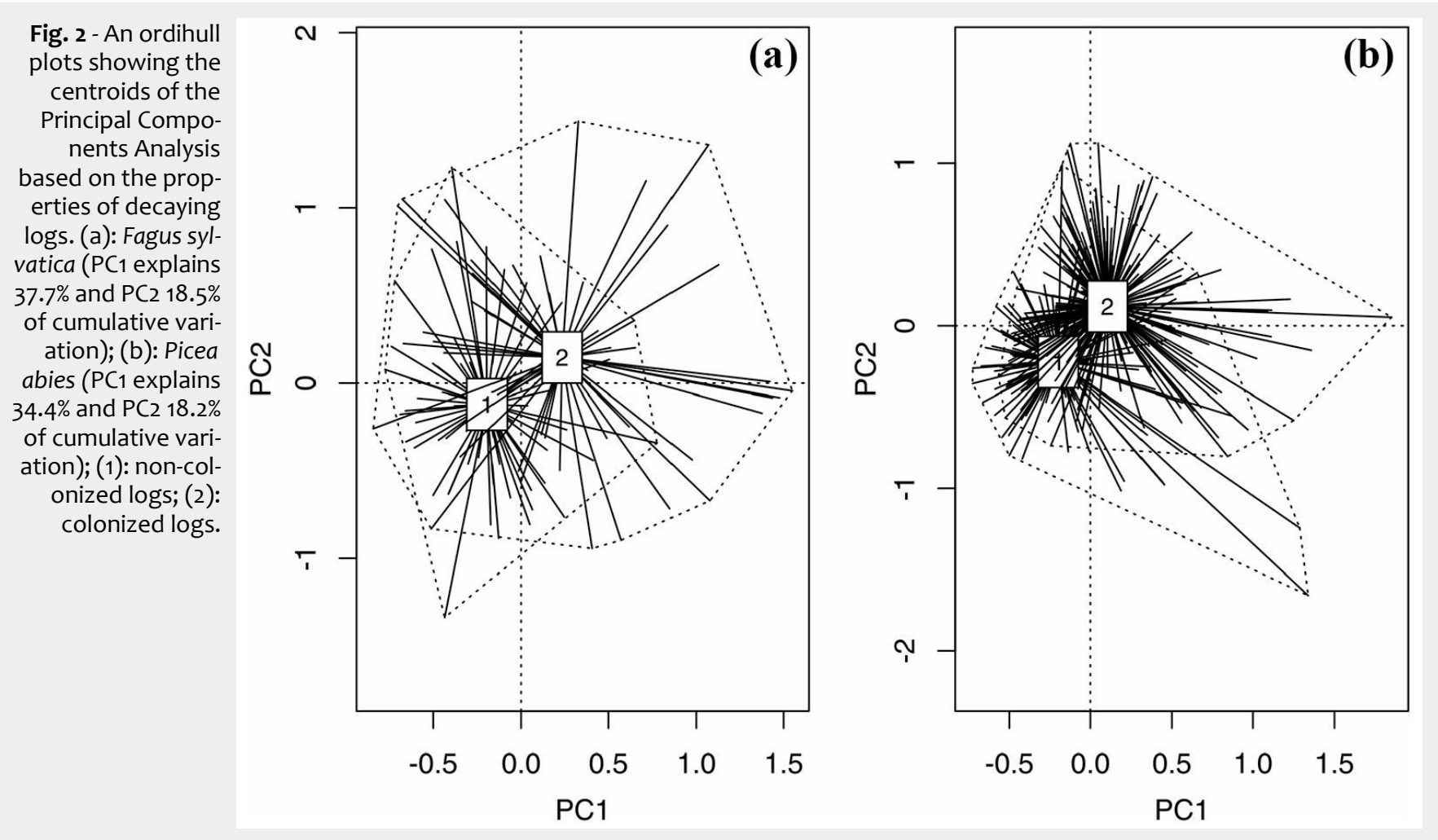


Tab. 3 - Logistic regression parameters and the predicted increase in the probability (\%) of the colonization of logs due to impact of independent variables. Only significant variables are shown.

\begin{tabular}{|c|c|c|c|c|c|c|}
\hline Species & Parameter & Estimate & SE & Z & $\mathbf{P}$ & $\begin{array}{l}\text { Increase in } \\
\text { probability (\%) }\end{array}$ \\
\hline \multirow{3}{*}{$\begin{array}{l}\text { Fagus } \\
\text { sylvatica }\end{array}$} & (Intercept) & -3.98 & 0.94 & -4.23 & 0.0000 & - \\
\hline & UPPER & 0.08 & 0.02 & 3.43 & 0.0006 & $\begin{array}{l}82.0 \text { for mean increase by } \\
0.1 \mathrm{~m}\end{array}$ \\
\hline & BRYOPHYTES & 0.03 & 0.01 & 2.99 & 0.0028 & $\begin{array}{l}26.0 \text { for mean increase } \\
\text { by } 10 \% \text { cover }\end{array}$ \\
\hline \multirow{5}{*}{$\begin{array}{l}\text { Picea } \\
\text { abies }\end{array}$} & (Intercept) & -6.03 & 1.05 & -5.72 & 0.0000 & - \\
\hline & ALTITUDE & 0.00 & 0.00 & 3.24 & 0.0012 & $\begin{array}{l}29.9 \text { for mean increase by } \\
100 \mathrm{~m}\end{array}$ \\
\hline & DECOMPOSITION & 0.63 & 0.12 & 5.45 & 0.0000 & $\begin{array}{l}88.6 \text { for mean increase by } \\
1 \text { class }\end{array}$ \\
\hline & LENGTH & 0.13 & 0.06 & 2.21 & 0.0270 & $\begin{array}{l}14.0 \text { for mean increase by } \\
1 \mathrm{~m}\end{array}$ \\
\hline & BRYOPHYTES & 0.05 & 0.01 & 5.40 & 0.0000 & $\begin{array}{l}50.0 \text { for mean increase by } \\
10 \% \text { cover }\end{array}$ \\
\hline
\end{tabular}

independent variables, i.e., the traits of the DECOMPOSITION had the highest effect of logs and site characteristics indicated that magnitude (i.e., almost $90 \%$ of colonization
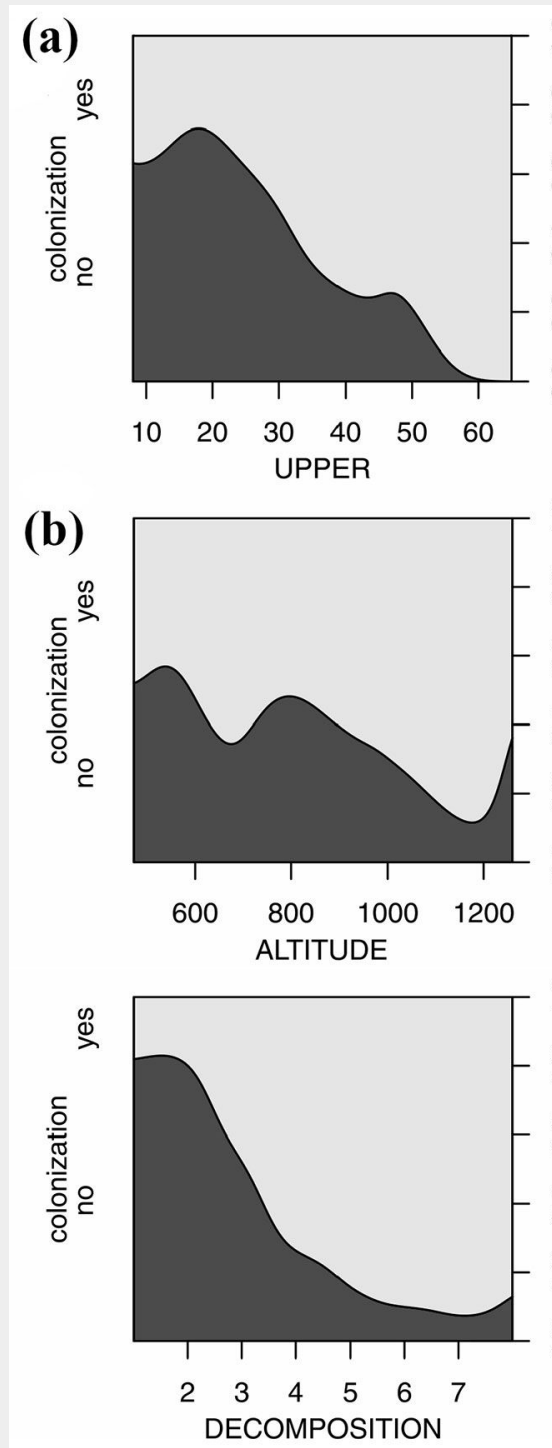
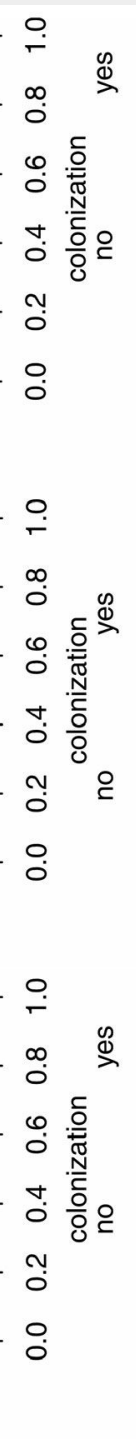
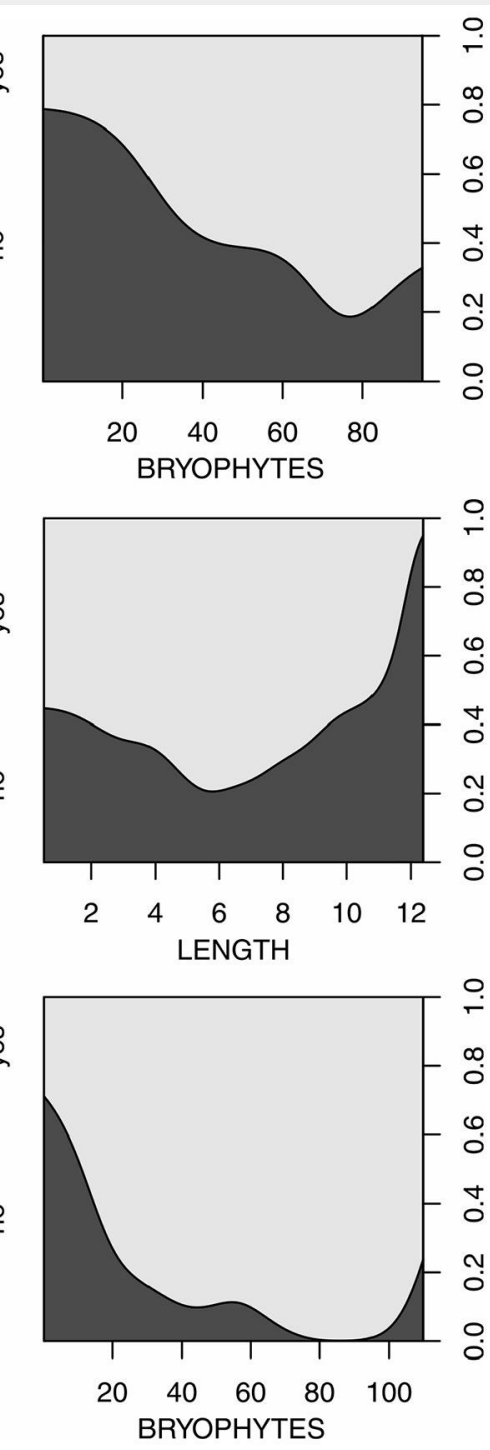

Fig. 3 - Plots of the conditional densities of probability of the colonization of logs (\%) by vascular plants due to selected variables. (a): F. sylvatica; (b): P. abies. probability) that enhanced the beginning of colonization in the spruce logs (Tab. 3, Fig. 3). The probability of colonization increased by ca. 30 \% in Picea abies for every 100 meters of ALTITUDE. In Fagus sylvatica, log size (UPPER) had a high impact (ca. $80 \%$ ) and BRYOPHYTES had a significant impact on the probability of colonization, although not as strong as in the case of spruce (Tab. 3, Fig. 3).

\section{Discussion}

Differences in colonization frequency between the two species

It was observed that both of the species studied, Fagus sylvatica and Picea abies, differed in the proportion of colonized logs. This finding can be associated with differences in the properties of the dead wood itself or the location of the logs. As for the former, we did not study the chemical properties of the dead wood, though the bark of both species could contain different biochemical compounds, which may have an impact on the colonization and development of plants (Petrillo et al. 2015). Norway spruce has a relatively smooth bark, low $\mathrm{pH}$ and a low nutrient content in decaying wood and it can also contain substances that inhibit plant development (Cornwell et al. 2009, Weedon et al. 2009, Checko et al. 2015). Beech has a much smoother bark than spruce. The microrelief of the bark itself could be an important factor that enables seed retention. When bark has many crevices and fissures, this also contributes to the capture of organic matter and humidity. Therefore, in order for beech logs to be colonized, they must be more decomposed.

Another factor that can bias the results is the vertical location, i.e., the mean and range of altitude where a given tree species is distributed. This was the main reason the species were studied separately.

\section{Role of decomposition in colonization frequency}

The various methods that were applied in this study (i.e., PCA, the comparison of the logs and the logistic regression) consistently selected more or less the same variables as being important determinants of colonization. As expected, colonized logs were generally characterized by a higher decomposition stage than those that were not colonized. The majority of literature sources have demonstrated that vascular plants begin to colonize fallen trees from the medium-decayed stage (Lee \& Sturgess 2001, Zielonka \& Piatek 2004, Chmura 2008, Nowinska et al. 2009, Staniaszek-Kik et al. 2014), but some studies have shown that this process can start earlier (Checko et al. 2015, Chmura 2014). It is an individualistic phenomenon, as our findings show that decomposition and class of decay make colonization three times more likely in the case of P. abies than in F. sylvatica, al- 
though the mean decomposition stage of beech was a little lower than spruce when colonized and non-colonized logs were compared. Our results are not in agreement with other findings revealing that broadleaved trees have better conditions for the recruitment and growth of vascular plants than conifers on lowlands (Nowinska et al. 2009). Moisture, which usually increases with decomposition rate (Bütler et al. 2007, Pichlerova et al. 2013, Petrillo et al. 2015), was higher in the colonized logs of $P$. abies. Non-colonized logs did not differ significantly in moisture from colonized logs only in beech.

\section{Role of bryophyte cover}

The bryophyte carpet that develops on the logs of beech and spruce facilitates the establishment of vascular plants. Its presence and abundance make colonization much more probable in spruce than in beech. In a previous study, we found a positive relationship between the cover of vascular plants and the cover of mosses on downed beech logs (Staniaszek-Kik et al. 2014). A similar positive relationship was encountered between the cover of vascular plants and the cover of bryophytes in the case of fallen spruce trees (StaniaszekKik et al. 2016). Many authors have emphasized the role of bryophytes in the establishment of vascular plants on CWD. Herbaceous plants and tree seedlings are facilitated by previous epiphytic mosses and later epixylic ones, which serve as reservoirs for water and accelerate soil accumulation (Checko et al. 2015 and literature cited therein). It was also observed that seed predation is reduced in the bryophyte mat (During \& Tooren 1990 and literature cited therein). Another critical and important phase in the life cycle, which is also affected by bryophytes, is germination and the emergence of seedlings. Among others, Nakamura (1992) reported the more successful emergence of vascular plant seedlings in bryophyte carpets, including mosses that were growing on logs. Mosses may also have played an important role in the colonization of the Norway spruce and beech by higher plants, which was reflected by a higher bryophyte cover in the downed trees of both species that were colonized in our study.

\section{Role of CWD size and altitude}

A significant effect of size on the colonization rate was found. Larger logs usually cause a higher coverage and species richness of vascular plants (Lee \& Sturgess 2001, Zielonka \& Piatek 2004, StaniaszekKik et al. 2014, Checko et al. 2015). This pattern is believed to be the result of the higher probability of diaspore retention due to size as well as slower decomposition, which makes the conditions more stable, a better ability to retain moisture and a higher frequency of visits by zoochores, i.e., animals that transport diaspores (Harmon et al. 1986, Lee \& Sturgess 2001, Van
Geffen et al. 2010). Larger and older beech trees have a more cracked bark and more crevices that can easily be colonized by plants. In spruce, the probability of colonization decreases in the case of large logs (Fig. 3b). Tall spruce trees are usually colonized at the base and at low heights.

The fact that spruce was colonized more frequently than the downed beech boles can be attributed to the differences in the altitudes at which both species lay. The frequency of colonization on downed spruce trees increased along with increasing altitude, whereas the colonization rate decreased in beech. The altitude is a proxy of climatic conditions such as temperature and precipitation, which can have a direct impact on both the decay rate and the germinability of seeds. One of the explanations of this phenomenon is the response of bryophytes to altitude. With increasing altitude, the humidity of the air and the moisture of the soil and litter also increases. This enhances the occurrence of epiphytic and epixylic species (StaniaszekKik et al., unpublished data). In spruce dominated stands, which are usually situated in the upper montane forest belt, there was a weak but positive relationship between the cover of bryophytes and altitude (Spearman's rank correlation $\rho_{\mathrm{s}}=0.13$, $p<0.01)$. Thus, with increasing altitude, bryophytes can enable more vascular plants to be established through the mechanisms mentioned above.

\section{Conclusions}

The observations indicated that vascular plants do not colonize all available logs and that the colonization process is not random. Despite the fact that the process of establishment, development and increase in the cover of plants during the later stages of decomposition is quite well recognized, it turns out that a more advanced stage contributes to the appearance of plants on logs. The more decayed the wood, the more suitable is to colonization by plants. The log size parameters (diameter and length), the altitude at which logs are located and the cover of bryophytes are other important factors that can facilitate plant colonization. The species identity of CWD can also influence the frequency of colonization. In our case, spruce turned out to be the more frequently colonized species compared to beech. Many log traits and the surrounding make colonization a species-specific process. More detailed studies are required to determine how the frequency of appearance of the coarse woody debris in forest ecosystems and the rate of its decomposition could influence the species pool of vascular plant colonizers and their relationships with cryptogamous plants.

\section{Acknowledgements}

We thank Michele Simmons for the language correction.

\section{References}

Brang P, Moran J, Puttonen P, Vyse A (2003). Regeneration of Picea engelmannii and Abies lasiocarpa in high-elevation forests of southcentral British Columbia depends on nurse logs. The Forestry Chronicle 79 (2): 273-279. - doi: 10.5558/tfc79273-2

Bütler R, Patty L, Le Bayon RC, Guenat C, Schlaepfer R (2007). Log decay of Picea abies in the Swiss Jura Mountains of central Europe. Forest Ecology and Management 242: 791-799. doi: 10.1016/j.foreco.2007.02.017

Checko E, Jaroszewicz B, Olejniczak K, Kwiatkowska-Falinska AJ (2015). The importance of coarse woody debris for vascular plants in temperate mixed deciduous forests. Canadian Journal of Forest Research 45 (9): 1154-1163. - doi: 10.1139/cjfr-2014-0473

Chmura D (2008). The colonization of coarse woody debris of Fagus sylvatica by forest herbs in Bukowica reserve (S Poland). Roczniki Akademii Rolniczej w Poznaniu Botanica Steciana 12: 3-7.

Chmura D (2014). Biology and ecology of an invasion of Impatiens parviflora DC in natural and semi-natural habitats. Wydawnictwo ATH, Bielsko-Biala, Poland, pp. 216.

Chmura D, Zarnowiec J, Staniaszek-Kik M (2016). Interactions between plant traits and environmental factors within and among montane forest belts: a study of vascular species colonising decaying logs. Forest Ecology and Management 379: 216-225. - doi: 10.1016/j.foreco.2016. 08.024

Cornwell WK, Cornelissen JHC, Allison SD, Bauhus J, Eggleton P, Preston CM, Scarff F, Weedon JT, Wirth C, Zanne AE (2009). Plant traits and wood fates across the globe: rotted, burned, or consumed? Global Change Biology 15: 2431-2449. - doi: 10.1111/j.1365-2486.2009.01 916.x

Dittrich S, Jacob M, Bade C, Leuschner C, Hauck $M$ (2014). The significance of deadwood for total bryophyte, lichen, and vascular plant diversity in an old-growth spruce forest. Plant Ecology 215 (10): 1123-1137. - doi: 10.1007/s11258014-0371-6

During HJ, Tooren BF (1990). Bryophyte interactions with other plants. Botanical Journal of the Linnean Society 104 (1-3): 79-98. - doi: 10.1111/j.1095-8339.1990.tbo2212.x

Harmon ME, Franklin JF, Swanson FJ, Sollins P, Gregory SV, Lattin JD, Anderson NH, Cline SP, Aumen NG, Sedell JR, Lienkaemper GW, Cromack Jr K, Cummins KW (1986). Ecology of coarse woody debris in temperate ecosystems. Advances in Ecological Research 15 (133): 133302. - doi: 10.1016/S0065-2504(08)60121-X

Holeksa J (2001). Coarse woody debris in a Carpathian subalpine spruce forest. Forstwiss Centralblatt 120: 256-270. - doi: 10.1007/BF0279 6097

Jüriado I, Paal J, Liira J (2003). Epiphytic and epixylic lichen species diversity in Estonian natural forests. Biodiversity Conservation 12 (8): 1587-1607. - doi: 10.1023/A:1023645730446 Kupferschmid AD, Bugmann H (2005). Effect of microsites, logs and ungulate browsing on Picea abies regeneration in a mountain forest. Forest Ecology and Management 205 (1): 251265. - doi: 10.1016/j.foreco.2004.10.008 
Lee P, Sturgess K (2001). The effects of logs, stumps, and root throws on understory communities within 28-year-old aspen-dominated boreal forests. Canadian Journal of Botany 79 (8): 905-916. - doi: 10.1139/bo1-072

Nakamura T (1992). Effect of bryophytes on survival of conifer seedlings in subalpine forests of central Japan. Ecological Research 7(2): 155-162. - doi: 10.1007/BF02348494

Nowinska R, Urbanski P, Szewczyk W (2009). Species diversity of plants and fungi on logs of fallen trees of different species in oak-hornbeam forests. Roczniki Akademii Rolniczej $w$ Poznaniu Botanica Steciana 13: 109-124.

Odor P, Van Hees AF (2004). Preferences of dead wood inhabiting bryophytes for decay stage, log size and habitat types in Hungarian beech forests. Journal of Bryology 26 (2): 7995. - doi: $10.1179 / 037366804225021038$

Ols C, Victorsson J, Jonsell M (2013). Saproxylic insect fauna in stumps on wet and dry soil: Implications for stump harvest. Forest Ecology and Management 290: 15-21. - doi: 10.1016/j.for eco.2012.08.040

Oksanen J, Blanchet FG, Friendly M, Kindt R, Legendre P, McGlinn D, Minchin PR, O'Hara RB, Simpson GL, Solymos P, Stevens MHH, Szoecs $E$, Wagner H (2016). The vegan package. Community ecology package, 10 . $R$ package version 2: 4-1. [online] URL: http://CRAN.R-project.org/ package $=$ vegan

Petrillo $M$, Cherubini $P$, Sartori $G$, Abiven S, Ascher J, Bertoldi D, Camin F, Barbero A, Lar- cher R, Egli M (2015). Decomposition of Norway spruce and European larch coarse woody debris (CWD) in relation to different elevation and exposure in an Alpine setting. iForest 9: 154-164. - doi: 10.3832/ifor1591-008

Pichlerova M, Homolak M, Pichler V, Kurjak D, Jaloviar P (2013). Importance of coarse woody debris (CWD) for moisture control and survival of Norway spruce (Picea abies L. Karst.) seedlings. Polish Journal of Ecology 61 (3): 471-476. [online] URL: http://www.miiz.waw.pl/pliki/arti cle/ar61_3_05.pdf

R Core Team (2015). R: a language and environment for statistical computing. $\mathrm{R}$ Foundation for Statistical Computing, Vienna, Austria. URL. [online] URL: http://www.R-project.org

Sefidi K, Etemad V (2015). Dead wood characteristics influencing macrofungi species abundance and diversity in Caspian natural beech (Fagus orientalis Lipsky) forests. Forest Systems 24 (2): eSC03. - doi: 10.5424/fs/2015242-06039 Staniaszek-Kik M, Zarnowiec J, Chmura D (2014). Colonization patterns of vascular plant species on decaying logs of Fagus sylvatica $L$. in a lower mountain forest belt: a case study of the Sudeten Mts. (southern Poland). Applied Ecology and Environmental Research 12 (3): 601-613. doi: 10.15666/aeer/1203_601613

Staniaszek-Kik M, Zarnowiec J, Chmura D (2016). The vascular plant colonization on decaying logs of Picea abies in mountain forest belts: the effects of forest community type, cryptogam cover, log decomposition and forest manage- ment. European Journal of Forest Research 135: 1145-1157. - doi: 10.1007/s10342-016-1001-8 Van Geffen KG, Poorter L, Sass-Klaassen U, Van Logtestijn RS, Cornelissen JH (2010). The trait contribution to wood decomposition rates of 15 neotropical tree species. Ecology 91 (12): 3686-3697. - doi: 10.1890/09-2224.1

Weedon JT, Cornwell WK, Cornelissen JHC, Zanne AE, Wirth C, Coomes DA (2009). Global meta-analysis of wood decomposition rates: a role for trait variation among tree species? Ecology Letters 12: 45-56. - doi: 10.1111/j.1461-0248. 2008.01259.x

Zielonka T (2006). When does dead wood turn into a substrate for spruce replacement? Journal of Vegetation Science 17 (6): 739-746. - doi: 10.1111/j.1654-1103.2006.tb02497.x

Zielonka T, Piatek G (2004). The herb and dwarf shrubs colonization of decaying logs in subalpine forest in the Polish Tatra Mountains. Plant Ecology 172 (1): 63-72. - doi: 10.1023/B:VE GE.0000026037.03716.fc

\section{Supplementary Material}

Tab. S1 - Species of vascular plants inhabiting decaying logs in the Karkonosze Mts. (Poland).

Tab. S2 - The description of GLM models used in this study.

Link: Chmura_2107@supploo1.pdf 